\title{
Seroprevalence and incidence of Toxoplasma gondii and Neospora caninum infection in naturally exposed domestic dogs from a rural area of São Paulo state, Brazil
}

\author{
Soroprevalência e incidência de infecção por Toxoplasma gondii e Neospora \\ caninum em cães domésticos naturalmente expostos em uma área rural no \\ estado de São Paulo, Brasil
}

\author{
Anaiá da Paixão Sevá1,2* (1D; Daniela Pontes Chiebao; Ana Perola Drulla Brandão; Silvia Neri Godoy4; \\ Tatiana Jimenez-Villegas ${ }^{1}$; Hilda Fátima Jesus Pena'; Fernando Ferreira ${ }^{1}$ \\ Departamento de Medicina Veterinária Preventiva e Saúde Animal, Universidade de São Paulo - USP, São Paulo, SP, Brasil \\ ${ }^{2}$ Departamento de Ciências Exatas e Tecnológicas, Universidade Estadual de Santa Cruz - UESC, Ilhéus, BA, Brasil \\ ${ }^{3}$ Centro de Pesquisa de Sanidade Animal, Instituto Biológico de São Paulo, São Paulo, SP, Brasil \\ ${ }^{4}$ Instituto Chico Mendes de Conservação da Biodiversidade, São Sebastião, SP, Brasil
}

\begin{abstract}
How to cite: Sevá AP, Chiebao DP, Brandão APD, Godoy SN, Jimenez-Villegas T, Pena HFJ, et al. Seroprevalence and incidence of Toxoplasma gondii and Neospora caninum infection in naturally exposed domestic dogs from a rural area of São Paulo state, Brazil. Braz J Vet Parasitol 2020; 29(3): e008820. https://doi.org/10.1590/S1984-29612020053
\end{abstract}

\begin{abstract}
Dogs are hosts of the protozoans Toxoplasma gondii, which causes an important public health disease, and Neospora caninum. Studies that have evaluated toxoplasmosis and neosporosis for prolonged periods in dog populations are rare. We analyzed infection by both parasites in a domestic dog population over three consecutive years in São Paulo state, Brazil. In the $1^{\text {st }}, 2^{\text {nd }}$ and $3^{\text {rd }}$ years of collection, 181, 193 and 172 domiciles were visited, and blood samples of 331, 371 and 348 dogs were collected for antibody serology, respectively. The seroprevalence of $T$. gondii in each year was $27.2 \%, 22.5 \%$ and $43.9 \%$, respectively, and that of $N$. caninum was $7.8 \%, 4.8 \%$ and $6.8 \%$, respectively. The incidence rates for $T$. gondii in the $2^{\text {nd }}$ and $3^{\text {rd }}$ collections were $13.2 \%$ and $30.0 \%$, and those for $\mathrm{N}$. caninum were $3.3 \%$ and $4.4 \%$, respectively. Positive and negative serological conversions for both agents occurred at high frequencies during the study period. This study reveals the canine population's serological profile and demonstrates the constant exposure of dogs to the investigated pathogens, indicating the need for prevention and control measures in the region.
\end{abstract}

Keywords: Canine, toxoplasmosis, neosporosis, Cãoservação Program, serology.

\begin{abstract}
Resumo
Os cães são hospedeiros dos protozoários Toxoplasma gondii, que causam uma importante doença para a saúde pública, e Neospora caninum. Estudos que avaliam a toxoplasmose e a neosporose por períodos prolongados em populações caninas são raros. Foi analisada a infecção por esses dois parasitas em uma população de cães domésticos e domiciliados por três anos consecutivos, no Estado de São Paulo, Brasil. Nos $1^{\circ}, 2^{\circ}$ e $3^{\circ}$ anos de coletas, 181, 193 e 172 domicílios foram visitados, nos quais foram coletadas amostras de sangue de 331, 371 e 348 cães para sorologia, respectivamente. A soroprevalência de $T$. gondii em cada ano foi de $27,2 \%, 22,5 \%$ e $43,9 \%$, respectivamente; e a de N. caninum foi de 7,8\%, 4,8\% e 6,8\%, respectivamente. As taxas de incidência para T. gondii, nas $2^{\mathrm{a}}$ e $3^{\mathrm{a}}$ coletas, foram de $13,2 \%$ e $30,0 \%$, respectivamente; e para $N$. caninum, 3,3\% e 4,4\%, respectivamente. As conversões sorológicas positivas e negativas para ambos os agentes ocorreram em alta frequência durante o período analisado. Este estudo revela o perfil sorológico da população canina e demonstra sua constante exposição aos patógenos investigados, o que requer medidas de prevenção e controle na região.
\end{abstract}

Palavras-chave: Canino, toxoplasmose, neosporose, Programa Cãoservação, sorologia. 


\section{Introduction}

Domestic dogs are one of the main reservoirs and hosts of pathogens that infect humans and other domestic and wild animals (Courtenay et al., 2001). Along with wild canids, they are definitive hosts of the Neospora caninum protozoan, eliminating the parasite in their feces (McAllister et al., 1998; McAllister, 1999) and thus playing an important role in disease dynamics (McAllister, 1999). In addition, domestic dogs are also intermediate hosts of the Toxoplasma gondii protozoan, and they can be a significant sentinel species for the presence of the agent in the environment and for human infections (Frenkel \& Parker, 1996; Salb et al., 2008; Cabezón et al., 2010).

Dogs become infected with N. caninum or T. gondii when they ingest oocysts from feces of definitive hosts, or eat raw or rare meat containing tissue cysts of infected intermediate hosts, such as domestic and wild animals (Dubey, 2003). N. caninum is the causative agent of neosporosis, which causes neurological clinical signs in this species (McAllister, 1999). This disease in ruminants is serious, with abortion as its main clinical symptom, suggesting economic importance for the cattle industry (Dubey et al., 2007). The definitive hosts of $T$. gondii are domestic and wild felids, and the intermediate hosts are homeothermic animals, including humans (Dubey \& Beattie, 1988). In dogs, clinical signs are rare (Dubey \& Beattie, 1988); however, toxoplasmosis is an important disease for public heath because it can cause abortion or neurologic or visual malformations in human fetuses (Dubey \& Jones, 2008). Domestic dogs are considered a potential source of agent transmission because they can mechanically transmit the agent by rolling in cat feces containing oocysts or by ingesting feces and excreting oocysts, contaminating the human environment (Lindsay et al., 1997).

The exposure of domestic dogs to these infectious agents and their close contact with humans increases their importance in the maintenance of these disease cycles. When dogs have free access to streets, they can feed on infected hosts (mostly small mammals) or become infected with parasite oocysts that have been eliminated in the feces of domestic cats. Increased T. gondii seroprevalence was observed in street and farm dogs when compared with confined dogs, suggesting that unconfined dogs can be an important source of infection (Souza et al., 2003).

Few studies have evaluated these parasitic infection courses over long periods considering natural dog population dynamics (including birth, entrance, death and exit), and few studies have identified the source of exposure to these infectious agents. This kind of study allows an understanding of the course of infection in specific habitats.

In some Brazilian Conservation Units (CUs), the presence of humans and domestic dogs living inside or surrounding these preserved areas, as well as wild animals inhabiting areas outside the CUs, is common. In this context, dogs infected with transmissible pathogens can indicate the presence of these infectious agents in the environment, and they can also represent a risk to all the involved populations. For example, wild animals can become infected by N. caninum eliminated by dogs. Humans and wild animals can become infected by oocysts of T. gondii carried by dogs.

The aim of this study was to evaluate domestic and domiciled dog populations that were naturally infected with T. gondii and N. caninum for three consecutive years. These dogs inhabited an area near a CU, and most of them had free access to the streets and, therefore, to the preserved area.

\section{Material and Methods}

\section{Study area}

The Carlos Botelho State Park (CBSP) is a Brazilian CU within a large Atlantic Rain Forest remnant located in São Paulo state (Figure 1). Near its limits, there are two neighborhoods in the São Miguel Arcanjo municipality: Abaitinga and Gaviões. Domestic dogs who live in these neighborhoods are commonly raised unrestrained, with access to the streets and thus to the CBSP (Figure 1). The collection area was characterized by a rural zone with a subtropical humid climate (annual average temperature of $18{ }^{\circ} \mathrm{C}$ and monthly average pluviosity over $40 \mathrm{~mm}$ ), without a dry season and with hot summers (Alvares et al., 2013). In this region, there were some individual family farms with dairy cows, and the study area covered the whole surrounding areas of the CBSP.

\section{Data collection}

Three sample collections were performed in the Abaitinga and Gaviões neighborhoods in April of 2015, 2016 and $2017\left(1^{\text {st }}, 2^{\text {nd }}\right.$ and $3^{\text {rd }}$ collection, respectively) by a census survey of households within the study area. All residences with dogs were georeferenced, and blood samples were collected from the animals for subsequent serological analyses of $T$. gondii and $N$. caninum infections. 

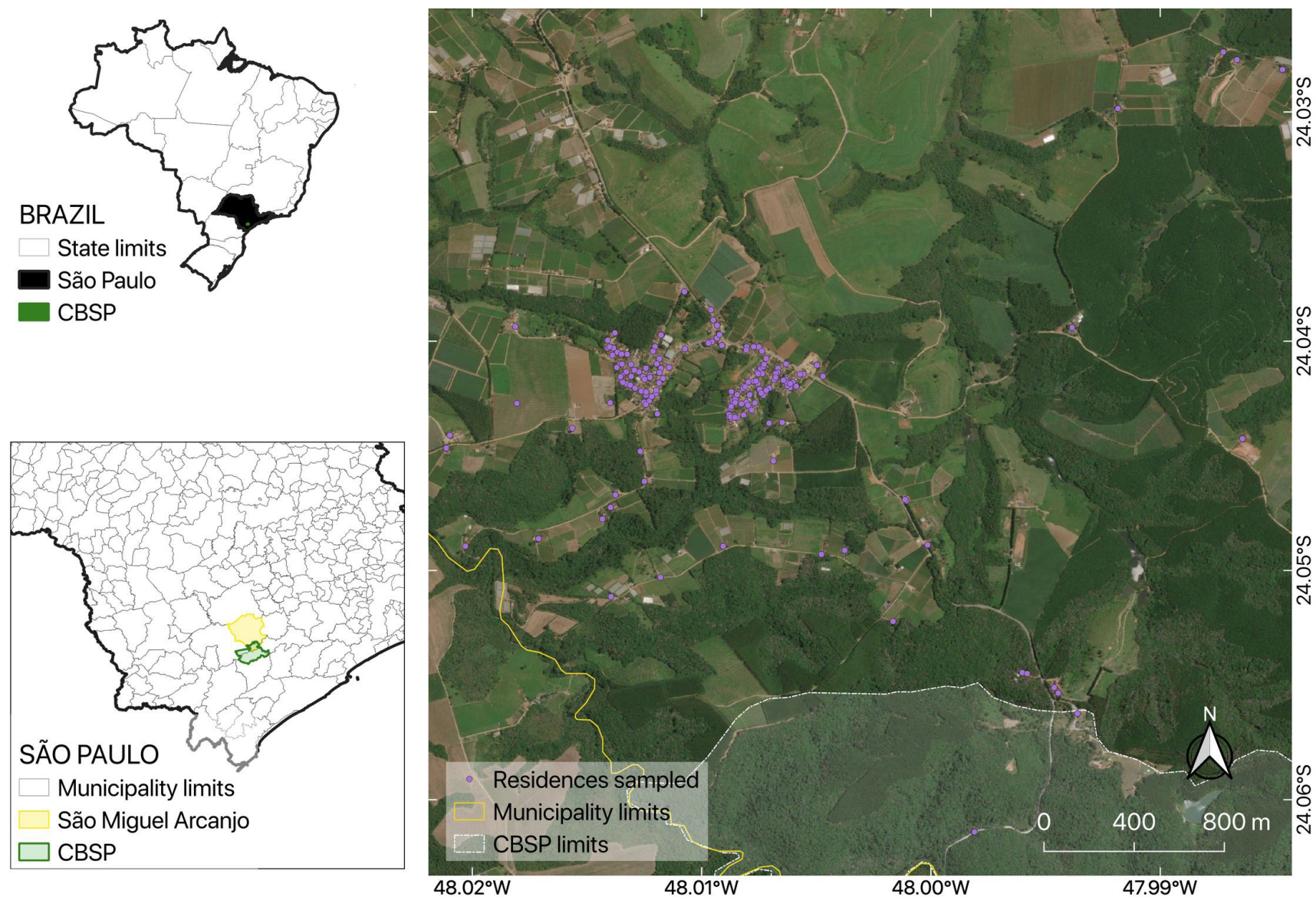

$48.02^{\circ} \mathrm{W}$

$48.01^{\circ} \mathrm{W}$

$48.00^{\circ} \mathrm{W}$

$47.99^{\circ} \mathrm{W}$

Figure 1. Residences of the dogs sampled in the study from São Miguel Arcanjo municipality, São Paulo state, Brazil. CBSP = Carlos Botelho State Park.

During the visits to the dogs' residences, the owners signed an informed consent form approved by the Animal Ethics Committee (CEUA) of the Faculty of Veterinary Medicine and Animal Science (FMVZ) of the University of São Paulo (USP) under protocol CEUA 2452231014.

\section{Sample collection}

Blood samples were collected from the jugular, femoral or cephalic veins of the dogs. These samples were stored in a refrigerator for at least five hours, followed by centrifugation at $1500 \mathrm{rpm}$ for 10 minutes to obtain sera. Serum samples were stored at $-20^{\circ} \mathrm{C}$ for subsequent analysis in the laboratory.

\section{Laboratory analysis}

\section{Immunofluorescence Antibody Test (IFAT)}

The detection of anti-T. gondii and anti-N. caninum antibodies was conducted by an immunofluorescence antibody test (IFAT) according to Camargo (1974) and Dubey \& Beattie (1988), with tachyzoites of the T. gondii RH strain and the N. caninum NC-1 strain, respectively. The tachyzoites were maintained by passage in cell culture using the Vero lineage. The slides were sensitized with tachyzoites obtained from a suspension of $10^{7}$ tachyzoites $/ \mathrm{mL}$ as antigens for IFAT. After drying at room temperature, the slides were fixed with methanol, stored in propylene boxes and kept at $-20^{\circ} \mathrm{C}$.

Sera were diluted in phosphate buffered saline solution using a cutoff of 1:64 for T. gondii and 1:50 for N. caninum. A specific anti-dog IgG antibody conjugated with fluorescein (Sigma, USA) was employed. The antigen-antibody reaction was visualized with immunofluorescence microscopy (Olympus BX60, Tokyo, Japan). Samples with tachyzoites with complete peripheral fluorescence were considered reagents, and these were serially two-fold 
diluted to determine the final reactivity titer. The readings were performed by only a single specialist among the research group. Negative and positive controls were used for each slide.

\section{Statistical analysis}

To compare the infection rates of the two parasites, chi-square tests were performed. For the annual analyses of the serological titers, Kruskal-Wallis tests were performed for each parasite, and Wilcoxon tests were also performed to determine statistical significance. Indexes of the prevalence in each year and incidence (rate of new cases) in the two last years for both infectious diseases were calculated with a confidence interval $(\mathrm{CI})$ of $95 \%$. All analyses were performed with R software version 3.5.0, considering a significance level of 5\%.

\section{Geographical distribution}

Using the geographical coordinates of the dogs' residences, maps were constructed to observe the spatial distribution of the seropositive and seronegative dogs infected with each parasite species. Kernel maps (quartic function) were constructed to show the intensity of seropositive animals in the study area. These analyses, as well as all the maps, were conducted and constructed using QGIS software (version 3.4).

\section{Results and Discussion}

At the $1^{\text {st }}, 2^{\text {nd }}$ and $3^{\text {rd }}$ collections, 181,193 and 172 domiciles were visited, respectively; only three refused to participate during the three sampling years. Approximately $75.0 \%$ of the residences had lot sizes smaller than $300 \mathrm{~m}^{2}$ and were near or within areas that included paved streets (defined as "houses"), 20.0\% were rural residences (defined as "country houses") and 5.0\% were residences on an agricultural farm (defined as "farms"). Regarding the blood samples, 331, 373 and 348 samples were collected in each year, corresponding to an average of $1.76,1.86$ and 1.84 dogs per domicile, respectively. A total of 585 dogs were sampled throughout the study period, and $26.8 \%$ (157) were sampled in all three years of the study. The owners reported that $55.4 \%$ (324/585) of dogs had free access to the streets. During the entire study period, some animals exited the study due to disappearance, death or permanent departure from the study area, and some entered the study due to birth or relocation to the study area. In addition, three dogs were sampled during only the $1^{\text {st }}$ and $3^{\text {rd }}$ collections because they could not be located during the $2^{\text {nd }}$ collection (Figure 2).

\section{$20152016 \quad 2017$}

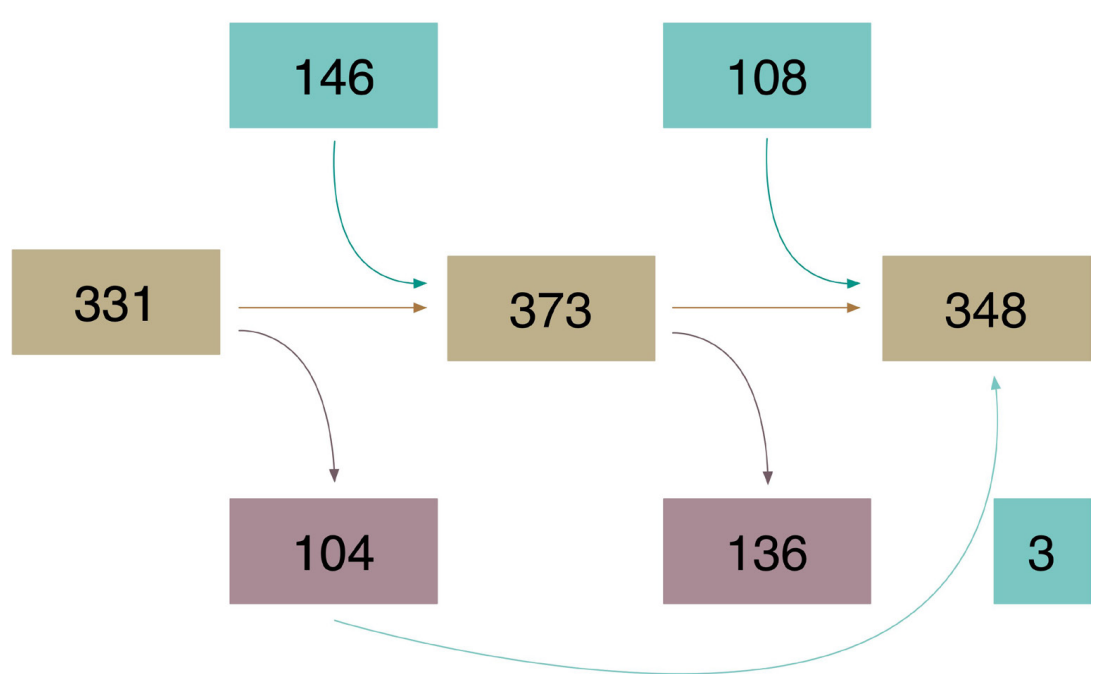

Figure 2. Population dynamics of dogs sampled in 2015, 2016 and 2017. Inside the boxes are the numbers of dogs sampled in each year (in brown), exits due to disappearance, death or relocation outside the study area (in purple) and entrances due to birth or relocation to the study area (in blue). 
The $T$. gondii seroprevalence in dogs was higher than the $N$. caninum seroprevalence, which is a frequent finding (Mascolli et al., 2015; Varandas et al., 2015). Regarding toxoplasmosis, in the $1^{\text {st }}, 2^{\text {nd }}$ and $3^{\text {rd }}$ collections, the percentages of dogs with positive reactions according to the IFAT were $27.2 \%$ (90/331; Cl: 22.8-32.4), 22.5\% (83/373; Cl: 20.4-26.9) and $43.9 \%$ (153/348; Cl: 39.0-49.5), respectively. The incidence rates for the $2^{\text {nd }}$ and $3^{\text {rd }}$ collections were $13.2 \%$ (30/227; Cl: 9.5-18.5) and 30.0\% (71/237; Cl: 24.6-36.4), respectively.

The increases in the seroprevalence and incidence in the $3^{\text {rd }}$ collection were significant when compared with the previous collections. This increased exposure to T. gondii can be explained by a high rate of ingestion of infected food sources, such as raw meat provided by their owners or infected prey.

The number of animals that entered into the study between the $2^{\text {nd }}$ and $3^{\text {rd }}$ collections was lower than the number that entered between the $1^{\text {st }}$ and $2^{\text {nd }}$ collection (Figure 2$)$, and $46.3 \%(50 / 108)$ were seropositive. Although these animals represented $70.4 \%(50 / 71)$ of the new cases in the $3^{\text {rd }}$ collection, it is not possible to know if they were infected before or after entrance into the study area. The number of positive dogs born between the $2^{\text {nd }}$ and $3^{\text {rd }}$ collection was $7.2 \%(11 / 71)$. There is no solid evidence of congenital infection of $T$. gondii in dogs (Dubey, 2010; Calero-Bernal \& Gennari, 2019).

Concerning neosporosis, for the $1^{\text {st }}, 2^{\text {nd }}$ and $3^{\text {rd }}$ collections, the prevalence rates were $7.8 \%(26 / 331 ; \mathrm{Cl}: 5.4-11.4)$, $4.8 \%(18 / 373 ; \mathrm{Cl}: 3.1-7.6)$ and $6.8 \%(24 / 348 ; \mathrm{Cl}: 4.7-10.1)$, respectively. The incidence rates for the $2^{\text {nd }}$ and $3^{\text {rd }}$ collections were 3.3\% (7/208; Cl: 1.6-7.0) and 4.4\% (10/227; Cl: 2.4-8.1), respectively; however, these differences were not statistical significants.

The $T$. gondii seroprevalence in adult and senior dogs is often high, with a cumulative effect according to age (Azevedo et al., 2005; Tenter et al., 2000). Most of the dogs that were seropositive for T. gondii in this study (47.1\%) were between four and nine years old. There was a statistically significant association between the age groups and the serological results for $T$. gondii in the $2^{\text {nd }}$ and $3^{\text {rd }}$ collections (Table 1 ). The proportion of positive puppies (less than one year old) was lower than the proportion of negative puppies. Additionally, the proportion of positive adults (four to nine years old) was higher than the proportion of negative adults. Although males were infected more frequently than females among the seropositive animals, there was no significant association between sex and the serological results (Table 1), similar to other studies (Cabezón et al., 2010; Constantino et al., 2016). On the other hand, some studies have proposed that males travel long distances and are thus more exposed to contaminated environments than females, increasing their risk of infection (Mascolli et al., 2015; Constantino et al., 2016).

Table 1. Seroprevalence of antibodies Anti-Toxoplasma gondii in domiciled domestic dogs of São Miguel Arcanjo municipality, São Paulo State, Brazil, according to age and sex in each collection.

\begin{tabular}{|c|c|c|c|c|c|c|c|c|c|c|c|c|c|c|c|c|}
\hline \multirow[b]{2}{*}{ Age group } & \multicolumn{5}{|c|}{$1^{\text {st }}$} & \multicolumn{5}{|c|}{$2^{\text {nd }}$} & \multicolumn{5}{|c|}{$3^{\text {rd }}$} & \multirow[b]{2}{*}{ Total } \\
\hline & & 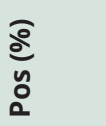 & & 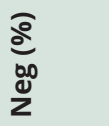 & $\frac{\frac{0}{2}}{\frac{1}{10}}$ & & $\frac{\varlimsup}{\stackrel{\varrho}{\varrho}}$ & & $\frac{ð}{\stackrel{0}{o}}$ & $\frac{0}{\frac{0}{2}}$ & & $\frac{\varlimsup}{\varrho}$ & & 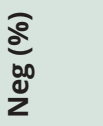 & $\frac{\frac{0}{2}}{\frac{1}{10}}$ & \\
\hline$<1$ & 7 & $(8.0)$ & 17 & (8.3) & 0.394 & 3 & (4.4) & 34 & (13.3) & $0.009 *$ & 11 & (8.4) & 33 & (20.1) & $0.032 *$ & 105 \\
\hline $1-3$ & 27 & (31.0) & 83 & $(40.5)$ & & 19 & (27.9) & 92 & (36.1) & & 47 & (35.9) & 55 & (33.5) & & 323 \\
\hline $4-9$ & 41 & $(47.1)$ & 86 & $(42.0)$ & & 32 & $(47.1)$ & 106 & (41.6) & & 64 & $(48.1)$ & 62 & (37.8) & & 390 \\
\hline$>=9$ & 12 & (13.8) & 19 & (9.3) & & 14 & $(20.6)$ & 23 & (9.0) & & 10 & (7.6) & 14 & $(8.5)$ & & 92 \\
\hline WI & 3 & & 36 & & & 15 & & 35 & & & 21 & & 31 & & & 141 \\
\hline Total & 90 & & 241 & & & 83 & & 290 & & & 153 & & 195 & & & 1052 \\
\hline Sex & & $\frac{\varrho}{\stackrel{0}{\varrho}}$ & & $\frac{ð}{\frac{0}{2}}$ & $\frac{0}{\frac{0}{3}}$ & & $\frac{\varlimsup}{\varrho}$ & & 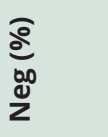 & $\begin{array}{l}\frac{0}{2} \\
\frac{1}{10} \\
\frac{1}{2}\end{array}$ & & 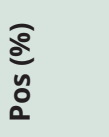 & & 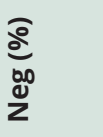 & $\frac{0}{\frac{0}{2}}$ & Total \\
\hline $\mathbf{F}$ & 38 & $(42.2)$ & 110 & $(46.6)$ & 0.534 & 37 & $(44.6)$ & 148 & $(51.4)$ & 0.319 & 72 & $(47.7)$ & 98 & $(50.8)$ & 0.588 & 503 \\
\hline$M$ & 52 & $(57.8)$ & 126 & $(53.4)$ & & 46 & (55.4) & 140 & $(48.6)$ & & 80 & $(52.3)$ & 95 & $(49.2)$ & & 538 \\
\hline WI & 0 & & 5 & & & 0 & & 2 & & & 1 & & 2 & & & 10 \\
\hline Total & 90 & & 241 & & & 83 & & 290 & & & 153 & & 195 & & & 1052 \\
\hline
\end{tabular}

$\mathrm{WI}$ = Without information; Pos = Positive; Neg = Negative; $\mathrm{F}=$ female; $M=$ male. *significant $(\mathrm{p}$-value $<0.05)$. 
Most of the dogs that were seropositive for N. caninum were also between four and nine years old; however, there was no significant association between age group and the serological results (Table 2), similar to other studies (Jesus et al., 2006; Melo et al., 2012). Seropositive males were also more prevalent than seropositive females in the $1^{\text {st }}$ and $2^{\text {nd }}$ collections, but there was no significant association, similar to other studies (Jesus et al., 2006; Melo et al., 2012; Constantino et al., 2016). In only one study, seropositive males were significantly more prevalent than seropositive females (Mascolli et al., 2015).

Table 2. Seroprevalence of antibodies Anti-Neospora caninum in domiciled domestic dogs of São Miguel Arcanjo municipality, São Paulo State, Brazil, according to age and sex in each collection.

\begin{tabular}{|c|c|c|c|c|c|c|c|c|c|c|c|c|c|c|c|c|}
\hline \multirow[b]{2}{*}{ Age group } & \multicolumn{5}{|c|}{2015} & \multicolumn{5}{|c|}{2016} & \multicolumn{5}{|c|}{2017} & \multirow[b]{2}{*}{ Total } \\
\hline & & $\frac{ð}{\stackrel{0}{0}}$ & & $\frac{\substack{0 \\
z}}{z}$ & $\frac{\frac{0}{2}}{\frac{1}{\pi}}$ & & $\frac{\varlimsup}{\stackrel{0}{0}}$ & & 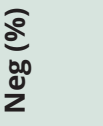 & $\frac{0}{\frac{0}{\pi}}$ & & $\frac{\precsim}{\stackrel{0}{0}}$ & & 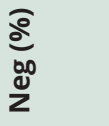 & $\begin{array}{l}\frac{0}{2} \\
\frac{\pi}{\pi} \\
\frac{1}{2}\end{array}$ & \\
\hline$<1$ & 0 & $(0)$ & 24 & (8.9) & 0.099 & 0 & (0) & 37 & $(12.0)$ & 0.125 & 1 & $(4.5)$ & 43 & $(15.7)$ & 0.1149 & 105 \\
\hline $1-3$ & 6 & $(26.1)$ & 104 & $(38.7)$ & & 3 & (18.7) & 108 & $(35.2)$ & & 5 & (22.7) & 98 & (35.5) & & 323 \\
\hline 4-9 & 12 & $(52.2)$ & 115 & $(42.7)$ & & 10 & $(62.5)$ & 128 & $(41.7)$ & & 23 & (59.1) & 112 & $(41.0)$ & & 390 \\
\hline$>=9$ & 5 & $(21.7)$ & 26 & (9.7) & & 3 & (18.7) & 34 & $(11.1)$ & & 3 & (13.6) & 21 & (7.7) & & 92 \\
\hline WI & 3 & & 36 & & & 2 & & 48 & & & 2 & & 50 & & & 141 \\
\hline Total & 26 & & 305 & & & 18 & & 355 & & & 24 & & 324 & & & 1052 \\
\hline Sex & & $\frac{\varrho}{\stackrel{\varrho}{\varrho}}$ & & 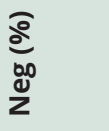 & $\begin{array}{l}\frac{0}{2} \\
\frac{2}{\pi} \\
\frac{1}{2}\end{array}$ & & $\frac{\varlimsup}{\varrho}$ & & 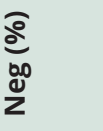 & $\begin{array}{l}\frac{0}{2} \\
\frac{2}{\pi} \\
\frac{1}{2}\end{array}$ & & $\frac{\varrho}{\varrho}$ & & 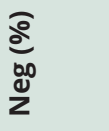 & $\begin{array}{l}\frac{0}{2} \\
\frac{2}{\pi} \\
\frac{1}{2}\end{array}$ & Total \\
\hline $\mathbf{F}$ & 12 & $(46.1)$ & 136 & (45.3) & 1.000 & 7 & $(41.2)$ & 178 & $(50.3)$ & 0.621 & 12 & $(52.2)$ & 158 & $(49.2)$ & 0.832 & 503 \\
\hline M & 14 & (53.8) & 164 & $(54.7)$ & & 10 & $(58.2)$ & 176 & $(49.7)$ & & 11 & $(47.8)$ & 164 & $(50.8)$ & & 538 \\
\hline WI & 0 & & 5 & & & 1 & & 1 & & & 1 & & 2 & & & 10 \\
\hline Total & 26 & & 305 & & & 18 & & 355 & & & 24 & & 324 & & & 1052 \\
\hline
\end{tabular}

$\mathrm{WI}=$ Without information; Pos = Positive; Neg = Negative; $\mathrm{F}=$ female; $\mathrm{M}=$ male.

Previously, increased prevalence rates were observed in areas around forests (Mascolli et al., 2015) and rural areas compared with urban areas (Boa Sorte et al., 2015; Benitez et al., 2017a). The seroprevalence rates of T. gondii were high in this study, suggesting that preying upon infected animals may be an important factor in maintaining infection in the canine population, as previously observed (Navarro et al., 1992; Camossi et al., 2008). The chance of dogs becoming infected with $T$. gondii is exacerbated due to their close contact with soil and their carnivorous behavior (Dubey \& Jones, 2008), preying on rodents and birds (Mascolli et al., 2015). In addition, the presence of synanthropic animals is a risk factor for dog seropositivity (Camossi et al., 2008), mostly among dogs with free access to streets. Drinking water from puddles is also a risk factor because parasite oocysts can survive in water for an extended period of time (Benenson et al., 1982; Bahia-Oliveira et al., 2003). These considerations reinforce the concept that domestic dogs can act as sentinels for toxoplasmosis in the environment (Gonçalez et al., 2010).

Dogs can also act as sentinel animals for human toxoplasmosis, although they are not a good indicator of human foodborne diseases (Benitez et al., 2017b) since some owners feed them homemade food including raw or undercooked meat that can contain parasites (Camossi et al., 2008; Salb et al., 2008). In addition, some dog behaviors, such as rubbing, smelling, or even eating cat feces, increase their role as an indirect vehicle for $T$. gondii transmission (Frenkel \& Parker, 1996). In another municipality of Brazil, a positive correlation between human and dog seroprevalence rates was observed, pointing to a possible common infection route for both populations (Garcia et al., 1999). The existence of at least one infected dog at the domicile was considered a risk factor for infection in their owners (Araujo et al., 2011).

The high prevalence and incidence rates of $T$. gondii in dogs in the present study lead us to believe that humans who live in the area are also constantly exposed to the agent. This exposure must have been increased 
in the last year of the study, as the incidence and prevalence rates in the $3^{\text {rd }}$ collection were higher than those in the other years. Additionally, 36.9\%, 34.2\% and 59.0\% of the residences had at least one positive dog in the $1^{\text {st }}, 2^{\text {nd }}$ and $3^{\text {rd }}$ collections, respectively.

In dogs, the risk factors for $N$. caninum are similar to those for $T$. gondii, although the transmission of N. caninum has been frequently related to feeding on aborted fetuses and/or placentas of infected cattle (McAllister, 1999) and congenital infection (Barber \& Trees, 1998). Some studies showed that the prevalence of $N$. caninum was higher in dogs living freely on farms and in streets (Azevedo et al., 2005; Regidor-Cerrillo et al., 2010). In the study area, cattle production is not common, suggesting that the dog incidence and prevalence rates may be due to their constant exposure to infected prey (synanthropic and wild animals) and/or meat provided by their owners. In the CBSP, there is a high abundance of small mammals, and the presence of domestic dogs inside the park is common (Brocardo et al., 2012). In the present study, the prevalence rates of residences with at least one N. caninum-seropositive dog were $11.2 \%, 8.0 \%$ and $11.2 \%$ in the 1 st, $2^{\text {nd }}$ and $3^{\text {rd }}$ collections, respectively.

T. gondii-seropositive dogs were identified throughout the study area, including the area near the CBSP (Figure 3A). The T. gondii results reinforce the need for the local population to be educated on the prevention of this important zoonosis. The distribution of $N$. caninum-seropositive dogs was generally restricted to the central area of the neighborhoods in all three collection years, although there were some positive dogs from farms in the $3^{\text {rd }}$ year (Figure 3B).
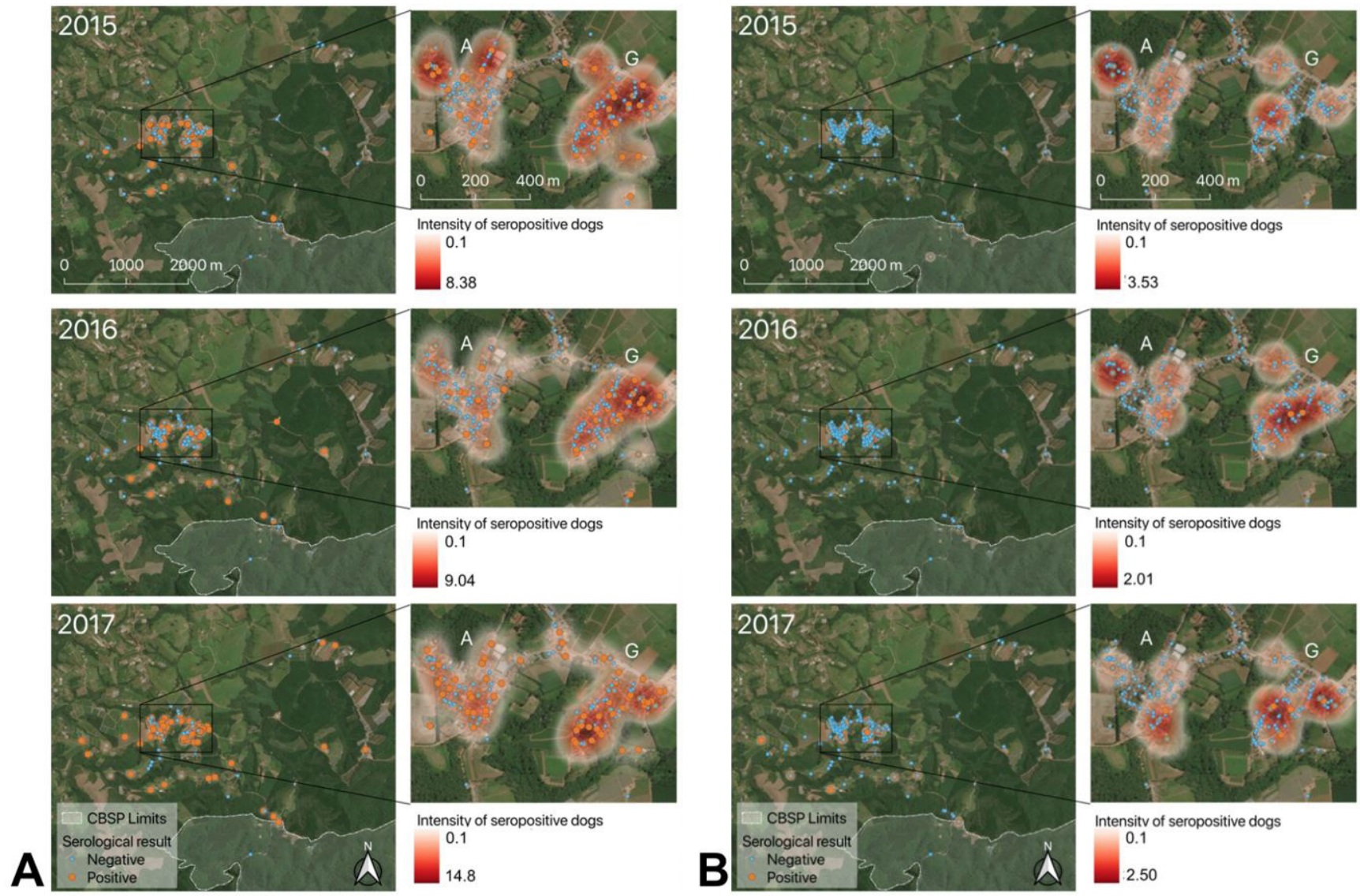

Figure 3. Distribution of dogs sampled in each year of the study according to their serological status for Toxoplasma gondii (A) and Neospora caninum (B), with a kernel map based on their serological titers. CBSP = Carlos Botelho State Park; Letters inside zoom maps: $\mathrm{A}$ = Abaitinga neighborhood; $\mathrm{G}$ = Gaviões neighborhood.

Regarding the intensity of the seropositive dogs in the area (Figure 3), the Gaviões neighborhood had high amounts of dogs with both parasite infections in all three years of the study, although the locality of these high intensities varied each year. The Abaitinga neighborhood had high numbers of dogs infected with both parasites, but high numbers infected with $N$. caninum were identified in only the $1^{\text {st }}$ collection. These results demonstrated that the transmission of the agents occurred throughout the residential region of the study area. 
The highest serological titer for $T$. gondii infection (Figure 1A Supplementary Material) was 16,384 in the $1^{\text {st }}$ collection. There was a statistically significant difference between only the titers from the $1^{\text {st }}$ (mean equal to 672.2) and $2^{\text {nd }}$ (mean equal to 1,193 ) collections ( $p$-value $=0.003$ ); the mean titer of the $3^{\text {rd }}$ collection was 806.6. The highest titer for N. caninum infection (Figure 1B Supplementary Material) was 25,600 among all of the collections. There were no significant differences between the serological titer means between the three collections. The highest mean occurred in the $2^{\text {nd }}$ collection $(2,800)$, followed by the $1^{\text {st }}(1,400)$ and $3^{\text {rd }}(800)$ collections.

The most frequent serological titer for $T$. gondii in the whole period of the study was 1:256 (22.3\% of the positive dogs) (Figure 2A Supplementary Material), similar to the study by Boa Sorte et al. (2015); this value was higher than those in other studies (Garcia et al., 1999; Mascolli et al., 2015; Benitez et al., 2017a). T. gondii infection in dogs is predominantly asymptomatic (Calero-Bernal \& Gennari, 2019), and according to Camargo (1974), low titers indicate a chronic or recent infection. In the present study, $22.3 \%$ (72/323) of the positive dogs had low titers (up to 1:64).

The most frequent serological titer for $N$. caninum among the three collections was 1:400 (22.4\%) (Figure 2B Supplementary Material), and the highest was 1:25,600, which is higher than those in other studies (Azevedo et al., 2005; Melo et al., 2012). Although serological titers have diagnostic relevance only when associated with clinical signs and when performed sequentially, Gondim reported that serological titers higher than 800 are hardly indicative of clinical neosporosis (Gondim, 2016); titers higher than 800 occurred in 62.7\% (42/67) of the dogs in the three years of this study. The main, although not very common, clinical signs in dogs are neurological disorders and neonatal mortality (Nolan et al., 2015).

Although no animals with evident typical clinical symptoms of toxoplasmosis or neosporosis were found, the prevalence rates and high titers suggest that both diseases should not be neglected and should be considered in differential diagnoses in animals with reproductive and neurological signs in small animal practices.

Among the dogs that were seropositive for $T$. gondii in at least one collection (96 animals), most were positive in only the $3^{\text {rd }}$ collection (32-33.3\%), followed by positive in both the $2^{\text {nd }}$ and $3^{\text {rd }}$ collections $(15-15.6 \%)$ and both the $1^{\text {st }}$ and $3^{\text {rd }}$ collections (15-15.6\%) (Figure 4); $5.2 \%$ of the dogs (five dogs) were positive in only the $2^{\text {nd }}$ collection, demonstrating a short period of seropositivity (less than one year). It is necessary to highlight that these animals presented titers from 1:64 to 1:512. In contrast to $T$. gondii, there were no N. caninum-seropositive dogs in only the $2^{\text {nd }}$ collection.

\section{Toxoplasma gondii}

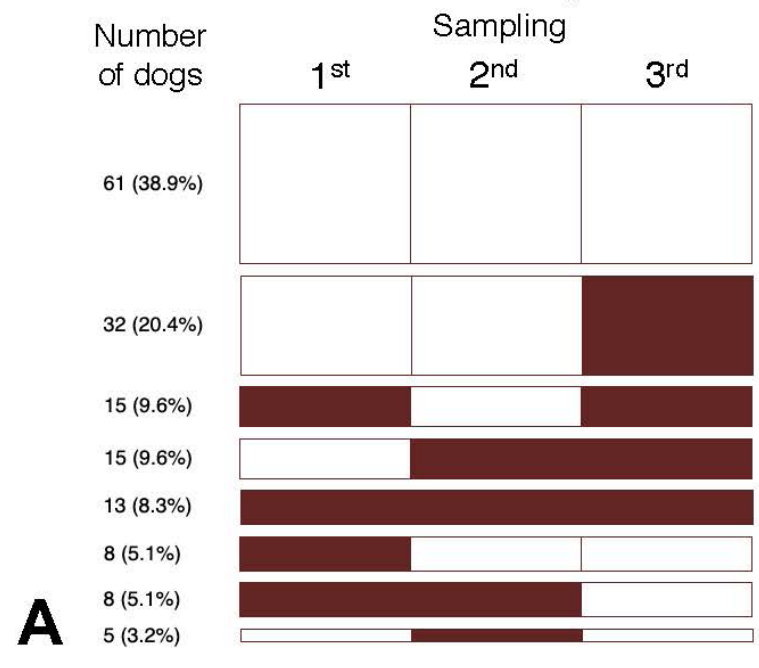

Neospora caninum

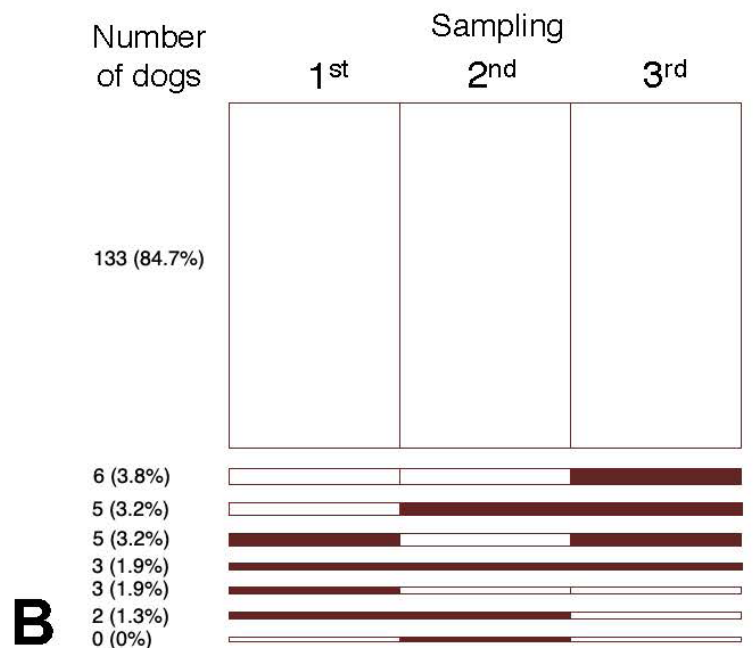

Figure 4. Dynamics of the serological status for Toxoplasma gondii (A) and Neospora caninum (B) infections over time in the studied dog population. The white boxes represent seronegative samples, and the brown boxes represent seropositive samples.

Among the dogs that were $T$. gondii- and $N$. caninum-seropositive only in both the $1^{\text {st }}$ and $3^{\text {rd }}$ collections, the serological titer means of the samples were 506.6 and 516.8 for $T$. gondii in the $1^{\text {st }}$ and $3^{\text {rd }}$ collections, respectively, and 2,823.7 and 2,784.6 for $N$. caninum in the $1^{\text {st }}$ and $3^{\text {rd }}$ collections, respectively. This result may be due to antibody reductions between the $1^{\text {st }}$ and $2^{\text {nd }}$ collection, followed by reactivation or reinfection before the $3^{\text {rd }}$ collection. When 
this occurs, the high titers decrease and increase again, although they are normally not as high as those in the primary infection (Silva et al., 2010; Chiebao et al., 2019).

The sensitivity and specificity of the IFAT changes based on the cutoff values established (Björkman \& Uggla, 1999). However, some authors have used this test as the gold standard to evaluate the accuracy of other tests for infection by both parasites (Cañón Franco et al., 2003). Meireles et al. used negative and positive T. gondii controls determined by the IFAT to standardize the enzyme-linked immunosorbent assay (ELISA) (Meireles et al., 2004). On the other hand, it is known that the sensitivity of the IFAT for T. gondii is lower than that of other serological tests for this parasite (Domingues et al., 1998; Silva et al., 2002; Freschi et al., 2005). It is important to consider that the IFAT has been found to be appropriate to avoid cross-reactivity between $N$. caninum and $T$. gondii in serum samples from different hosts (Silva et al., 2007; Benetti et al., 2009).

In each year, the rates of coinfection by both parasites were 3.0\% (95\% Cl 1.6-5.5\%), 1.6\% (95\% Cl 0.7-3.5\%) and 3.4\% (95\% Cl 1.9-6.0\%), respectively (Table S1). Varandas et al. (2015) and Higa et al. (2000) found similar coinfection rates $(5.8 \%$ and $4.8 \%$, respectively) in dogs. The number of seropositive dogs infected with both parasites and with only N. caninum remained similar in all three collections. The number of animals infected with only $T$. gondii decreased slightly from the $1^{\text {st }}$ to the $2^{\text {nd }}$ collection and almost doubled from the $2^{\text {nd }}$ to the $3^{\text {rd }}$ collection (Table S1).

In the present study, the seroprevalence rates for T. gondii were lower than those in other studies; however, the most frequent titer values were higher than those in other studies. The seroprevalence rates and the titer values for $N$. caninum were similar to those of other studies. When the incidence rates of both parasites were high and the spatial distribution occurred throughout the area, it was possible to conclude that they were circulating at the local level with host exposure.

Toxoplasmosis is an important disease for public health. It is possible to conclude the need for prevention and control measures, such as washing hands, washing vegetables and fruits before eating, not feeding cats or dogs raw or undercooked meat and removing animal feces from the ground, in the study area (Etheredge et al., 2004). Responsible dog ownership and dog sterilization programs can control the population and hence reduce the number of free-ranging animals on the streets and in the state park.

Although neosporosis is not an important disease for humans, it is important for cattle and wild animals. In the study area, there was only one cattle farm; however, it was near a reserve with wild animals. In that case, reducing domestic and free-ranging dogs in that environment can also contribute to preventing transmission of the agent.

As the scenario of the present study is common in some regions of Brazil, our analyses, as well as the proposed strategies for preventing parasitic infections, can be applied in other areas to preserve the health of humans and animals.

\section{Conclusion}

Dogs are constantly exposed to T. gondii and $N$. caninum in the areas surrounding the CBSP, a Brazilian Conservation Unit. The prevalence and incidence of infection by $N$. caninum were lower than those by T. gondii in the study period. Prevention measures, such as health education for dog owners, are necessary, as T. gondii is an important zoonosis.

\section{Acknowledgements}

Funding was provided by the Research Support Foundation of São Paulo State (process numbers 2015/21954-8 and 2015/21966-6).

\section{References}

Alvares CA, Stape JL, Sentelhas PC, Gonçalves JLM, Sparovek G. Köppen's climate classification map for Brazil. Meteorol Z (Berl) 2013; 22(6): 711-728. http://dx.doi.org/10.1127/0941-2948/2013/0507.

Araujo DA, Silva AV, Zanette DF, Silva DR, Correa NAB, Veslasquez LG, et al. Investigation of factors associated with Toxoplasma gondii infection in dogs and human beings from Porto Figueira, PR. Vet Zootec 2011; 18(1): 98-111.

Azevedo SS, Batista CSA, Vasconcellos SA, Aguiar DM, Ragozo AMA, Rodrigues AAR, et al. Seroepidemiology of Toxoplasma gondii and Neospora caninum in dogs from the state of Paraíba, Northeast region of Brazil. Res Vet Sci 2005; 79(1): 51-56. http://dx.doi. org/10.1016/j.rvsc.2004.10.001. PMid:15894024. 
Bahia-Oliveira LMG, Jones JL, Azevedo-Silva J, Alves CCF, Oréfice F, Addiss DG. Highly endemic, waterborne toxoplasmosis in North Rio de Janeiro State, Brazil. Emerg Infect Dis 2003; 9(1): 55-62. http://dx.doi.org/10.3201/eid0901.020160. PMid:12533282.

Barber JS, Trees AJ. Naturally occurring vertical transmission of Neospora caninum in dogs. Int J Parasito/ 1998; 28(1): 57-64. http:// dx.doi.org/10.1016/S0020-7519(97)00171-9. PMid:9504335.

Benenson MW, Takafuji ET, Lemon SM, Greenup RL, Sulzer AJ. Oocyst-transmitted toxoplasmosis associated with ingestion of contaminated water. N Eng/J Med 1982; 307(11): 666-669. http://dx.doi.org/10.1056/NEJM198209093071107. PMid:7110216.

Benetti AH, Schein FB, Santos TR, Toniollo GH, Costa AJ, Mineo JR, et al. Pesquisa de anticorpos anti-Neospora caninum em bovinos leiteiros, cães e trabalhadores rurais da região Sudoeste do Estado de Mato Grosso. Rev Bras Parasito/ Vet 2009;18(e1 Suppl 1): 29-33. http://dx.doi.org/10.4322/rbpv.018e1005. PMid:20040187.

Benitez AD, Martins FDC, Mareze M, Santos NJR, Ferreira FP, Martins CM, et al. Spatial and simultaneous representative seroprevalence of anti-Toxoplasma gondii antibodies in owners and their domiciled dogs in a major city of southern Brazil. PLoS One 2017b; 12(7): e0180906. http://dx.doi.org/10.1371/journal.pone.0180906. PMid:28732033.

Benitez AN, Gonçalves DD, Nino BSL, Caldart ET, Freire RL, Navarro IT. Seroepidemiology of toxoplasmosis in humans and dogs from a small municipality in Paraná, Brazil. Cienc Anim Bras 2017a; 18(0): e42102. http://dx.doi.org/10.1590/1089-6891v18e-42102.

Björkman C, Uggla A. Serological diagnosis of Neospora caninum infection. Int J Parasitol 1999; 29(10): 1497-1507. http://dx.doi. org/10.1016/S0020-7519(99)00115-0. PMid:10608435.

Boa Sorte EC, Almeida ABPF, Cruz FACS, Gasparetto ND, Godoy I, Dutra V, et al. Serological and molecular detection of Toxoplasma gondii in dogs of urban and rural areas of Cuiaba, Mato Grosso. Semina: Ciênc Agrár 2015; 36(6): 3705-3712. http://dx.doi. org/10.5433/1679-0359.2015v36n6p3705.

Brocardo CR, Rodarte R, Bueno RS, Culot L, Galetti M. Non-volant mammals of Carlos Botelho State Park, Paranapiacaba Forest Continuum. Biota Neotrop 2012; 12(4): 198-208. http://dx.doi.org/10.1590/S1676-06032012000400021.

Cabezón O, Millán J, Gomis M, Dubey JP, Ferroglio E, Almería S. Kennel dogs as sentinels of Leishmania infantum, Toxoplasma gondii, and Neospora caninum in Majorca Island, Spain. Parasitol Res 2010; 107(6): 1505-1508. http://dx.doi.org/10.1007/s00436010-2015-7. PMid:20689966.

Calero-Bernal R, Gennari SM. Clinical toxoplasmosis in dogs and cats: an update. Front Vet Sci 2019; 6: 54. http://dx.doi.org/10.3389/ fvets.2019.00054. PMid:30863754.

Camargo ME. Introdução às técnicas de imunofluorescência. Rev Bras Patol Clín 1974; 10: 143-171.

Camossi LG, Faccioli PY, Menozzi BD, Daher SR, Langoni H. Environmental risk factors for canine toxoplasmosis in a deprived district of Botucatu, SP, Brazil.J Venom Anim Toxins Incl Trop Dis 2008; 14(3): 450-465. http://dx.doi.org/10.1590/S1678-91992008000300006.

Cañón Franco WA, Bergamaschi DP, Richtzenhain LJ, Nogueira Y, Camargo LMA, Souza SLP, et al. Evaluation of the performance of the modified direct agglutination test (MAT) for detection of Toxoplasma gondii antibodies in dogs. Braz J Vet Res Anim Sci 2003; 40(6): 452-456. http://dx.doi.org/10.1590/S1413-95962003000600009.

Chiebao DP, Pena HF, Passarelli D, Santín T, Pulz LH, Strefezzi RF, et al. Congenital transmission of Toxoplasma gondii after experimental reinfection with Brazilian typical strains in chronically infected sheep. Front Vet Sci 2019; 6: 93. http://dx.doi. org/10.3389/fvets.2019.00093. PMid:31001545.

Constantino C, Pellizzaro M, Paula EFE, Vieira TSWJ, Brandão APD, Ferreira F, et al. Serosurvey for Leishmania spp., Toxoplasma gondii, Trypanosoma cruzi and Neospora caninum in neighborhood dogs in Curitiba - Paraná, Brazil. Rev Bras Parasitol Vet 2016; 25(4): 504-510. http://dx.doi.org/10.1590/s1984-29612016062. PMid:27925057.

Courtenay O, Quinnell RJ, Chalmers WSK. Contact rates between wild and domestic canids: no evidence of parvovirus or canine distemper virus in crab-eating foxes. Vet Microbiol 2001; 81(1): 9-19. http://dx.doi.org/10.1016/S0378-1135(01)00326-1. PMid:11356314.

Domingues LM, Machado RZ, Costa MT, Carvalho CC, Costa AJ, Malheiros EB. Canine toxoplasmosis: a comparative evaluation of the detection of anti-Toxoplasma gondii antibodies by the indirect immunoenzymaticassay (ELISA) and the indirect immunofluorescence reaction (IIF). Rev Bras Parasitol Vet 1998; 7(2): 79-85.

Dubey JP, Beattie CP. Toxoplasmosis of animals and man. Boca Raton: CRC Press; 1988.

Dubey JP, Jones JL. Toxoplasma gondii infection in humans and animals in the United States. Int J Parasitol 2008; 38(11): 12571278. http://dx.doi.org/10.1016/j.jpara.2008.03.007. PMid:18508057.

Dubey JP, Schares G, Ortega-Mora LM. Epidemiology and control of neosporosis and Neospora caninum. Clin Microbiol Rev 2007; 20(2): 323-367. http://dx.doi.org/10.1128/CMR.00031-06. PMid:17428888.

Dubey JP. Review of Neospora caninum and neosporosis in animals. Korean J Parasitol 2003; 41(1): 1-16. http://dx.doi.org/10.3347/ kjp.2003.41.1.1. PMid:12666725. 
Dubey JP. Toxoplasmosis of animals and humans. 2nd ed. Beltsville: CRC Press; 2010.

Etheredge GD, Michael G, Muehlenbein MP, Frenkel JK. The roles of cats and dogs in the transmission of Toxoplasma infection in Kuna and Embera children in eastern Panama. Rev Panam Salud Publica 2004; 16(3): 176-186. http://dx.doi.org/10.1590/S102049892004000900004. PMid:15507185.

Frenkel JK, Parker BB. An apparent role of dogs in the transmission of Toxoplasma gondii. The probable importance of xenosmophilia. Ann N Y Acad Sci 1996; 791(1): 402-407. http://dx.doi.org/10.1111/j.1749-6632.1996.tb53546.x. PMid:8784520.

Freschi CR, Higa AC, Tinucci Costa M, Pancracio HP, Machado RZ. Caracterização de antígenos de Toxoplasma gondii, pela técnica de "Western Blotting", em soros de cães com sinais clínicos suspeitos de toxoplasmose. Ars Vet 2005; 21(2): $265-271$.

Garcia JL, Navarro IT, Ogawa L, Oliveira RC. Soroepidemiologia da toxoplasmose em gatos e cães de propriedades rurais do município de Jaguapitã, estado do Paraná, Brasil. Cienc Rural 1999; 29(1): 99-104. http://dx.doi.org/10.1590/S010384781999000100018 .

Gonçalez CC, Paes AC, Langoni H, Da Silva RC, Greca H, Camossi LG, et al. Anticorpos para Leptospira spp., Toxoplasma gondii e Neospora caninum em cães errantes albergados em canil privado. Arq Bras Med Vet Zootec 2010; 62(4): 1011-1014. http://dx.doi. org/10.1590/S0102-09352010000400037.

Gondim LFP. Neosporose. In: Megid J, Ribeiro MG, Paes AC, editors. Doenças infecciosas em animais produção e Cia. 1. ed. Rio de Janeiro: Roca; 2016. p. 1032-1039.

Higa AC, Machado RZ, Tinucci-Costa M, Domingues LM, Malheiros EB. Evaluation of cross-reactivity of Toxoplasma gondii and Neospora caninum antigens in dogs sera. Rev Bras Parasitol Vet 2000; 9(2): 91-95.

Jesus EEV, Santos POM, Barbosa MVF, Pinheiro AM, Gondim LFP, Guimarães JE, et al. Frequência de anticorpos anti-Neospora caninum em cães nos municípios de Salvador e Lauro de Freitas, Estado da Bahia - Brasil. Braz J Vet Res Anim Sci 2006; 43(1): 5-10. http://dx.doi.org/10.11606/issn.1678-4456.bjvras.2006.26511.

Lindsay DS, Dubey JP, Butler JM, Blagburn BL. Mechanical transmission of Toxoplasma gondii oocysts by dogs. Vet Parasito/ 1997; 73(1-2): 27-33. http://dx.doi.org/10.1016/S0304-4017(97)00048-4. PMid:9477489.

Mascolli R, Soto FRM, Bernardi F, Ito FH, Pinheiro SR, Guilloux AGA, et al. Seroprevalence and risk factors for toxoplasmosis and neosporosis in the dog population of Ibiúna, São Paulo, Brazil. Semina: Ciênc Agrár 2015; 36(6): 3777-3785. http://dx.doi. org/10.5433/1679-0359.2015v36n6p3777.

McAllister MM, Dubey JP, Lindsay DS, Jolley WR, Wills RA, McGuire AM. Rapid communication: dogs are definitive hosts of Neospora caninum. Int J Parasitol 1998; 28(9): 1473-1478. http://dx.doi.org/10.1016/S0020-7519(98)00138-6. PMid:9770635.

McAllister MM. Uncovering the biology and epidemiology of Neospora caninum. Parasitol Today 1999; 15(6): 216-217. http:// dx.doi.org/10.1016/S0169-4758(99)01457-X. PMid:10366825.

Meireles LR, Galisteo AJ Jr, Pompeu E, Andrade HFJr. Toxoplasma gondii spreading in an urban area evaluated by seroprevalence in free-living cats and dogs. Trop Med Int Health 2004; 9(8): 876-881. http://dx.doi.org/10.1111/j.1365-3156.2004.01280.x. PMid:15303992.

Melo ALT, Silva GCP, Aguiar DM. Soroprevalência de anticorpos anti-Neospora caninum em cães da cidade de Cuiabá, Estado de Mato Grosso. Semina: Ciênc Agrár 2012; 33(4): 1507-1514. http://dx.doi.org/10.5433/1679-0359.2012v33n4p1507.

Navarro IT, Vidotto O, Tudury EA, Vianna CC, Freire RL. Prevalência de anticorpos Anti-Toxoplasma gondii em cães atendidos no hospital veterinário da UEL- PR. Semina: Ciênc Agrár 1992; 13(1): 66-69. http://dx.doi.org/10.5433/1679-0359.1992v13n1 p66.

Nolan SJ, Romano JD, Luechtefeld T, Coppens I. Neospora caninum recruits host cell structures to its parasitophorous vacuole and salvages lipids from organelles. Eukaryot Cell 2015; 14(5): 454-473. http://dx.doi.org/10.1128/EC.00262-14. PMid:25750213.

Regidor-Cerrillo J, Pedraza-Diaz S, Rojo-Montejo S, Vazquez-Moreno E, Arnaiz I, Gomez-Bautista M, et al. Neospora caninum infection in stray and farm dogs: seroepidemiological study and oocyst shedding. Vet Parasitol 2010; 174(3-4): 332-335. http:// dx.doi.org/10.1016/j.vetpar.2010.08.033. PMid:20851523.

Salb AL, Barkema HW, Elkin BT, Thompson RCA, Whiteside DP, Black SR, et al. Dogs as sources and sentinels of parasites in humans and wildlife, Northern Canada. Emerg Infect Dis 2008; 14(1): 60-63. http://dx.doi.org/10.3201/eid1401.071113. PMid:18258078.

Silva AV, Cutolo AA, Langoni H. Comparação da reação de imunofluorescência indireta e do método de aglutinação direta na detecção de anticorpos anti-Toxoplasma em soros de ovinos, caprinos, caninos e felinos. Arq Inst Biol 2002; 69(1): 7-11.

Silva DAO, Lobato J, Mineo TWP, Mineo JR. Evaluation of serological tests for the diagnosis of Neospora caninum infection in dogs: optimization of cut off titers and inhibition studies of cross-reactivity with Toxoplasma gondii. Vet Parasitol 2007; 143(3-4): 234-244. http://dx.doi.org/10.1016/j.vetpar.2006.08.028. PMid:16973287.

Silva RC, Souza LC, Langoni H, Tanaka EM, Lima VY, Silva AV. Risk factors and presence of antibodies to Toxoplasma gondii in dogs from the coast of Sao Paulo State, Brazil. Pesq Vet Bras 2010; 30(2): 161-166. http://dx.doi.org/10.1590/S0100-736X2010000200011. 
Souza SLP, Gennari SM, Yai LEO, D'Auria SRN, Cardoso SMS, Guimarães JS Jr, et al. Occurrence of Toxoplasma gondii antibodies in sera from dogs of the urban and rural areas from Brazil. Rev Bras Parasitol Vet 2003; 12(1): 1-3.

Tenter AM, Heckeroth AR, Weiss LM. Toxoplasma gondii: from animals to humans. Int J Parasito/ 2000; 30(12-13): 1217-1258. http://dx.doi.org/10.1016/S0020-7519(00)00124-7. PMid:11113252.

Varandas NP, Rached PA, Costa GHN, Souza LM, Castagnolli KC, Costa AJ. Freqüência de anticorpos anti-Neospora caninum e anti-Toxoplasma gondii em cães da região nordeste do Estado de São Paulo. Correlação com neuropatias. Semina: Ciênc Agrár 2015; 22(1): 105-111. http://dx.doi.org/10.5433/1679-0359.2001v22n1p105. 


\section{Supplementary Material}

Supplementary material accompanies this paper.

Table S1. Serological results of all the dogs sampled in each year, relating to coinfection (Toxoplasma gondii and Neospora caninum)

S1 Figure. Serological titers of the dog samples in each Toxoplasma gondii (A) and Neospora caninum (B) collection according to the immunofluorescence antibody test.

S2 Figure. Distribution of the serological titers for Toxoplasma gondii (A) and Neospora caninum (B) in seropositive dogs in all the collections.

This material is available as part of the online article from http://www.scielo.br/rbpv 